Pobrane z czasopisma Wschód Europy http://journals.umcs.pl/we

Data: 26/04/2023 14:07:41

DOI:10.17951/we.2019.5.1.51-67

Wschód Europy • Восток Европы • East of Europe vol 5, 1 / 2019

Денис Сосунов

ORCID: https://orcid.org/0000-0003-2344-6526

Воронежский государственный университет, Россия

\title{
Архитектура принятия политических решений в современной России в контексте президентской вертикали власти Владимира Путина
}

$\mathrm{B}$

условиях серьезных внешних и внутренних вызовов современная Россия испытывает запас прочности всей политической системы, которая выстраивалась по принципу централизации и усиления роли исполнительной ветви власти. В этом процессе ключевую роль сыграл Президент РФ В. В. Путин, активно проводивший на этом посту реформы в области государственного строительства. Безусловно, претерпела изменения и сама архитектура системы принятия важнейших решений, испытавшая на себе влияние Президента РФ. В этом отношении особую актуальность приобретает вопрос о ключевых «контурах» данной архитектуры, методологических подходах к анализу политических решений, инструментов формирования политической повестки дня России и роли интернет-технологий в современной политической жизни. Кроме того, для широкой общественности Запада остается актуальной тема о самом «архитекторе» созданной системы принятия решений и вопрос «Who is mister Putin?» для многих продолжает быть открытым. Именно поэтому целью данной работы является рассмотрение наиболее эффективных теоретических моделей анализа процесса принятия политических решений, описание в этом процессе основных трендов формирования политической повестки дня на примере современной России, а также политико-психологическая характеристика стиля принятия решений Президента РФ В. В. Путина.

\section{Теоретическая ретроспектива}

Рассматривая ключевые контуры архитектуры принятия политических решений, необходимо вначале выяснить основные теоретические модели и подходы к анализу подобных решений. Стоит отметить, что обозначенная научная проблематика привлекала внимание ученых с древнейших времен. Однако по-настоящему формирование основ теории принятия решений произошло в XX веке. 
Один из самых «старых» методологических подходов к анализу политических решений - институциональный подход. Достаточно продолжительное время (примерно до 30-х гг. XX-го столетия) он составлял одну из доминирующих методологических традиций в США и Великобритании. Основное внимание представители этого подхода уделяли изучению весьма важного аспекта политического процесса, создающего «систему координат» для его протекания - политических институтов.

Данный подход представлен большим количеством течений. Одним из них является новый институционализм, теоретики которого делают упор на исследование неформальной структуры политических институтов. Кроме того, неоинституционалисты внесли весомый вклад в разработку вопросов о нормах, правилах, регламентах, организационных иерархиях и т.д. Яркий представитель этого течения Дж. Марч, который вместе с коллегами разработал известную модель организационного выбора в виде «мусорной корзины».

Эта модель описывает процесс принятия решений как хаотичное и беспорядочное взаимодействие или сочетание разнообразных «элементов», которые могут появляться и исчезать случайным образом независимо друг от друга. К таким «элементам», наполняющим «корзину», Дж. Марч относит проблемы, решения, участников организации и альтернативы ${ }^{1}$. Здесь на первый план, помимо прочего, выступают еще и психологические характеристики политического руководителя, его манера поведения и т.д. Изучение подобных «параметров» связывают с так называемым бихевиоралистическим направлением.

Классическая модель бихевиорализма была разработана в работах Г. Лассуэлла. В самом общем плане эта модель предполагает, что на микроуровне принятие решений связано с индивидуальным поведением самых разных людей, которые обладают личными мотивами и чувствами. Таким образом, в механизме принятия решений должны учитываться психологические характеристики личности политического лидера.

В 1960-1970-е г.г. наступил кризис бихевиорализма, на смену которого была разработана парадигма рационального выбора. У ее истоков стоял Э. Даунс, сформулировавший основные положения данного направления в своем труде «Экономическая теория демократии». Значительный вклад внесли также такие ученые как М. Олсон, Дж. Бьюкенен, Г. Таллок и др.

Процесс принятия политических решений в рамках парадигмы рационального выбора описывают чаще всего в виде модели «ограниченной рациональности», либо в рамках теории общественного выбора, которая последовательно развенчивает миф о государстве, не ставящем перед собой никаких иных целей, кроме заботы об общественных интересах.

Теория общественного выбора - это теория, изучающая различные способы и методы, посредством которых люди используют правительственные уч-

1 Цит. по: О. Кулагин, Принятие решений в организациях, Санкт-Петербург 2001, с. 96. 
реждения в своих собственных интересах. Сторонники теории общественного выбора, по сути дела, рассматривают политический рынок, на котором взаимодействуют избиратели, политики и государственные служащие. «Политика есть сложная система обмена между индивидами, в которой последние коллективно стремятся к достижению своих частных целей, так как не могут реализовать их путем обычного рыночного обмена»², - писал лауреат Нобелевской премии Дж. Бьюкенен.

Как отмечалось выше, в рамках парадигмы рационализма разработана модель, получившая название «неполной» или «ограниченной» рациональности Г. Саймона. В своей концептуальной модели американский ученый обосновывает положение, согласно которому политические решения принимаются не с помощью рационального процесса, а на основе упрощенных представлений о реальной ситуации, поэтому учитываются не только информационные издержки, но и когнитивные ограничения.

Существуют модели групповой репрезентации интересов, объясняющие подобные явления. Самые популярные из них - неокорпоративизм и плюрализм. Одним из самых ярких теоретиков плюралистической концепции, безусловно, является Роберт Даль. В 1967 г. он опубликовал учебник «Плюралистическая демократия в США», в котором более обстоятельно описал основополагающие аксиомы американского плюрализма, при этом указал на ряд его преимуществ: 1) власть контролируема, а применение силы минимизировано; 2) целью является согласие всех граждан (в конечном итоге); 3) система благоприятствует мирному разрешению конфликтов к взаимной выгоде большей части, если не всех, противодействующих сторон ${ }^{3}$. Эти положения Р. Даль последовательно, шаг за шагом, развивает в своей теории полиархии ${ }^{4}$, в которой фокусируется внимание на различных аспектах механизма принятия политических решений в современных демократиях.

В 1970 - 90-е годы широкую популярность получила еще одна теория репрезентации интересов в принятии политических решений - неокорпоративизм. Ее появление было стимулировано кризисом претерпевшего бюрократическое окостенение общества «всеобщего благосостояния» в странах Западной Европы и США. Как отмечал один из основателей данного направления Ф. Шмиттер, в этот период накопилась большая часть острых нерешенных проблем, среди которых он выделил следующие: 1) склонность прибегать к беспрецедентным незаконным средствам политического выражения; 2) ослабление сплоченности

2 Дж. Бьюкенен, Конституичия экономической политики, «Вопросы экономики» 1994, № 6, с. 108.

3 Дж. Мэнли, Неоплюрализм: анализ двух видов плюрализма с позиций классовой теории,

[в:] Теория и практика демократии. Избранные тексты (пер. с англ.), ред. В. Л. Иноземцев,

Б. Г. Капустин, Москва 2006, с. 326.

4 См. об этом подробнее: Р. Даль, Демократия и ее критики (пер. с англ.), Москва 2003, с. 576. 
элиты и ее господствующего положения; 3) сокращение способности государства обеспечивать ресурсы и реализовывать политические программы 5 .

Очевидно, что в этой системе основными агентами влияния в принятии конкретных решений будут выступать корпорации, обладающие своеобразной спецификой. Они жестко ориентированы на реализацию четко осознанных, узких групповых интересов и структурированы не только по горизонтали, но и по вертикали. Корпорации представляют собой некое подобие партий, которые, однако, в отличие от настоящих партий, добиваются своих целей не в рамках публичной политики, а путем прямого, чаще всего неофициального воздействия на политические структуры, сотрудничая, а то и сращиваясь с ними. При этом используется изощренная система аппаратного «продавливания» необходимых им управленческих и хозяйственных решенийб.

Среди российских исследований выделяется концепция известного политолога А.И. Соловьева, предложившего интересный подход в серии статей «Колебательно-маятниковый механизм принятия государственных решений: к обоснованию когнитивной модели», в котором механизм принятия государственных решений представлен как многоярусная, плюрально институционализированная, но при этом центрированная структура колебательно-маятникового типа с одновременно и многократно смещаемыми контурами активности Этот теоретический концепт предполагает несколько уровней принятия решений. Одним из ключевых является политический уровень, на котором главным источником выработки и продвижения решения выступает политическая воля лидеров. Институт лидера обеспечивает выработку стратегических целей и определение наиболее актуальных проблем, необходимых для внесения в политическую повестку дня.

Предлагаемая А. И. Соловьевым модель учитывает асинхронность (обусловленную относительно автономным функционированием структур власти и управления), многоуровневость и многояростность (неоднозначность взаимосвязей различных органов власти), а также мультисегментированность (связанную с множественностью секторов, зон ответственности и полномочий госструктур при выработке управленческих целей) процесса принятия государственных решений ${ }^{8}$.

5 См.: Ф. Шмиттер, Увязка интересов и управляемость политических режимов в современной Западной Европе и Северной Америки, [в:] Теория и практика демократии. Избранные тексты (пер. с англ.), ред. В.Л. Иноземцев, Б. Г. Капустин, Москва 2006, с. 342.

6 См.: А. Галкин, Корпоративизм как форма отношений между государством и обществом: предель и опасности, „Политические исследования” 2000, №6, с. 151.

7 См.: А. Соловьев, Колебательно-маятниковый механизм принятия государственных решений: к обоснованию когнитивной модели (II), „Политические исследования” 2005, № 6, c. 44 .

8 А. Соловьев, Колебательно-маятниковый механизм принятия государственных решений: к обоснованию когнитивной модели (II), „Политические исследования” 2005, №6, с. 46. 
Pobrane z czasopisma Wschód Europy http://journals.umcs.pl/we

Data: 26/04/2023 14:07:41

Архитектура принятия политических решений в современной России...

Именно поэтому, на наш взгляд, представленная теоретическая конструкция является наиболее эффективной для анализа политических решений. В ней особое внимание уделяется уровню, где ключевую роль играют политические лидеры.

\section{Политико-психологическая характеристика стиля принятия решений В. В. Путина}

Процесс принятия решений, безусловно, предполагает творческо-интелектуальную активность лица, принимающего решение, выступающего в роли своеобразного «архитектора» общественно-политического ландшафта. В этом процессе особую роль играют его личные качества. Как точно заметил Фред И. Гринстайн, «[л]ичности политических акторов, т.е. личные качества, отличающие одного индивида от другого, воздействуют на политические события бесчисленными путями, это нередко имеет далеко идущие последствия»9.

Однако прежде чем дать политико-психологическую характеристику стиля принятия политических решений (ППР $)^{10}$ лидером, необходимо разобраться в теоретических основах понятия «стиль».

В книге под редакцией авторитетного отечественного ученого Е. В. Егоровой-Гантман «Имидж лидера. Психологическое пособие для политиков» под стилем принятия политических решений понимаются индивидуальные методы принятия решений, а также отмечается, что методы, например, президентского принятия решений могут меняться не только в зависимости от личности политического лидера, но также и от обсуждаемой проблемы. Помощники Президента, от которых он зависит в данный момент, события, которые занимают его мысли, - все это, взаимодействуя с его установками, влияет на принятие решений ${ }^{11}$.

В качестве основных компонентов стиля ППР выделяют следующие:

1) подход к получению новой информации;

2) характеристики мышления;

3) предпочтение определенной величины риска;

4) когнитивная сложность, т.е. способность к анализу и синтезу;

5) информационные процессы;

6) способность противостоять двойственности ${ }^{12}$.

Приступая к анализу некоторых характеристик стиля ППР В. В. Путина по данной структуре, зададимся вопросом: валидны ли будут результаты этого анализа? Ведь у нас не было прямого доступа к Президенту РФ и, таким образом, анализ и интерпретацию данных мы проводили на дистанции. В этом отноше-

9 Д. Райгородский, Психология и психоанализ власти, Т. 2. Хрестоматия, Самара 1999, с. 69.

10 Далее для простоты изложения используется общепринятое сокращение - ППР.

11 Имидж лидера. Психологическое пособие для политиков, ред. Е. В. Егорова-Гантман, http:// www.forsuccess.ru, доступ 07.08.2018.

12 Ibidem. 
нии мы постарались сконцентрировать внимание на исследовании выступлений, речей, интервью и прочих вербальных материалов. «В любом высказывании говорящий или пишущий, даже не осознавая этого, рассказывает нам очень много о себе самом» ${ }^{13}$, - подчеркивал американский исследователь У. Лангер.

Итак, перейдем непосредственно к рассмотрению структурных элементов стиля ППР В. В. Путина. Один из наиболее существенных таких элементов - это характеристики мышления политического лидера. В 2000 г. группа психологов по заказу газеты «Известия» составила психологический портрет Путина. По их мнению, он относится к прагматически мыслящим интровертам, принимающим решения с опорой на логику и организующим работу наиболее рациональным способом ${ }^{14}$.

Логичность мышления Президента РФ прослеживалась, в частности, в его официальных выступлениях. Например, М. В. Гаврилова на основе Послания Президента Федеральному Собранию РФ 2002 г. выявила, что риторическим средством создания логической аргументации служит такая фигура прибавления, как стык: «важнейшими критериями успеха становятся лучшие мировые образиы. Образиы во всем». Эта фигура, передающая развитие мысли, демонстрирует логичность и последовательность изложения. Помимо этого, рационально-логическую стройность придает тексту Послания четкое распределение глагольного вида и времени. Так, например, о достигнутых страной результатах В. В. Путин говорил, используя преимущественно глагольные формы прошедшего времени совершенного вида («в некоторых регионах уже появился первый успешный опыт ипотечного жилищного кредитования») $)^{15}$.

Следующая важная характеристика - это скорость мышления. В нестандартных, кризисных или даже стрессовых ситуациях от политического лидера всегда ждут быстрых адекватных действий. В публичных выступлениях политик должен молниеносно реагировать на выпады своих оппонентов. Например, как это было во время первого в России саммита «Большой восьмерки», который проходил в Санкт-Петербурге. В. В. Путин изящно парировал неуклюжие атаки Дж. Буша, в частности, когда Президент США сказал, что Кремль должен брать пример демократии с Ирака.... Необходимо подчеркнуть, что обозначенная характеристика достаточно ярко проявляется и на современном этапе в ходе немногочисленных личных встреч с Президентом Д. Трампом и другими мировыми лидерами.

Некоторые психологи обращают внимание на то, что у В. Путина выработано определенное стереотипное мышление, а изменение дается очень тяжело, т.к. другой реальности он не воспринимает. В его выступлениях, особенно в ча-

13 Цит. по: Г. Почепцов, Стратегический анализ: стратегический анализ для политики, бизнеса и военного дела, Киев 2004, с. 253.

14 Т. Батенева, Неопознанньй шагающий объект, „Известия”, 16.02.2000, с. 7.

15 М. Гаврилова, Когнитивные и риторические основы президентской речи (на материале выступлений В.В. Путина и Б.Н. Ельцина), Санкт-Петербург 2004, с. 186. 
сти «импровизации», ярко представлен понятийно-фразеологический комплекс, идентифицированный с советским периодом. В. Путин как человек (нетворческого характера) должен был усваивать определенные стереотипные способы существования системы и четко следовать им на протяжении своей карьеры. А стереотипной для него является система КГБ-ФСБ и все, что из нее вытекает ${ }^{16}$. Начиная с первого срока своего президентства, он последовательно «воскрешал» государственную символику уже несуществующей страны. Так, например, с изменениями был восстановлен государственный гимн на слова С. Михалкова, различным родам войск вручены как новые штандарты, так и существовавшие в советское время. В ходе обсуждения законопроекта «О Знамени Победы» Президент РФ, по сути дела, поддержал Совет Федерации, выступавший за сохранение на знамени советской символики в виде серпа и молота. Вообще, В. В. Путин признал, что «крушение Советского Союза было крупнейшей геополитической катастрофой века» ${ }^{17}$.

Одним общим блоком попытаемся теперь рассмотреть подход к получению новой информации и сами информационные процессы. Очевидно, получение и обработка информации о состоянии и тенденциях развития политических процессов - необходимая предпосылка для комплексного, системного изучения конкретной проблемы.

Можно точно сказать, что В. В. Путин тяготеет к получению информации из «первых уст», этим можно объяснить его частые встречи с руководителями различных эшелонов власти. «Было подсчитано, что если Ельцин имел в последние годы своего пребывания в Кремле всего три-четыре встречи в неделю, то у Путина таких встреч было в 2000 году по шесть-семь ежедневно» ${ }^{18}$. При этом, насыщенный график личных встреч сохраняется и в настоящее время.

На вопрос о том, какие СМИ читает и смотрит Президент России, В. В. Путин ответил: «Я стараюсь смотреть все крупные и значимые, влияющие на мировое общественное мнение каналы, просматривать информационные сводки практически всех ваших агентств - и выдержки, и в прямом изложении» ${ }^{19}$. Следовательно, можно констатировать, что Президент РФ предпочитает получать информацию в комбинированной форме.

Еще одна характерная черта, связанная с подходом к информации - это стремление получать ее из разных источников. Косвенным подтверждением тому является ответ В. Путина на вопрос о возможном слиянии ФСБ с МВД. Он подчеркнул, что «...с точки зрения интересов ведомств, это может быть и нор-

16 Т. Батенко, Портрет Путина: вопрос над ответами, http://www.day.kiev.ua, доступ 07.06.2007.

17 Послание Президента России В. Путина: Послание Президента РФ Федеральному Собранию, http://www. kremlin.ru, доступ 25.06.2005.

18 Р. Медведев, Владимир Путин - действующий президент, Москва 2002, с. 195.

19 В. Путин, «Ответы на вопросы на Всемирном конгрессе инбормационных агентств «Информация: выззовы ХХІ века», http://www.kremlin.ru, доступ 24.09.2004. 
мально, но с точки зрения политических интересов, невыгодно - лучше получать информацию из двух источников (курсив мой - Д.С.), чем из одного» ${ }^{20}$.

B. В. Путин предпочитает всегда владеть всей полнотой информации и здесь, конечно, сказывается его происхождение, его формирование как сотрудника внешней разведки КГБ ${ }^{21}$. Еще одной характерной чертой стиля В. Путина является его постоянное желание подстраховаться от возможной «утечки» информации. Так, российская фирма «Гарант» отследила 1000 официальных решений В. Путина в качестве действующего и.о. Президента за январь и февраль 2000 г. «Больше половины шло под кодами „ДСП” и „секретно”, около 100 касались незначительных кадровых перестановок и политических назначений. Остальные, по заключению компании, не выдавали никакой определенной позиции по вопросам, волнующим российское общество» ${ }^{22}$.

В фильме В. Соловьева «Миропорядок 2018», отвечая на вопрос о том, как определяется внешняя политика России, принимает ли решения исключительно глава государства, или существует определенный круг лиц, влияющих на этот процесс, В. Путин отметил, что не хотел бы в деталях рассказывать о «кухне» принятия решений, «это неправильно, это такая сакральная вещь» ${ }^{23}$. Таким образом, непубличный характер стиля принятия политических решений стал своего рода «визитной карточкой» действующего Президента России.

В упоминавшейся уже работе Егоровой-Гантман предпочтение определенной величины риска рассматривается одновременно с таким критерием стиля ППР как «гибкость - жесткость». Исходя из этого, приводятся несколько вариаций стиля ППР:

1) гибкий стиль со склонностью к риску;

2) гибкий, но со склонностью к осторожности;

3) жесткий со склонностью к риску;

4) жесткий со склонностью к осторожности ${ }^{24}$.

По нашему мнению, В. Путину в наибольшей степени соответствует гибкий стиль, но со склонностью к осторожности. Президент РФ, судя по всему, в ходе сбора необходимой информации способен тщательно и критически оценивать возможные альтернативы. Из-за этого нередко создается впечатление, что подготовительная стадия перед принятием политического решения выглядит несколько затянутой.

Умение вести переговоры, добиваться компромисса непременно являются атрибутами гибкого стиля. Во время работы в мэрии г. Санкт-Петербурга В. Путин часто выполнял «деликатные» поручения своего руководителя А. Собчака:

\footnotetext{
20 В. Путин, От первого лица: Разговоры с Владимиром Путиным, Москва 2000, с. 128.

В. Печенев, Владимир Путин - последний шанс России?, Москва 2001, с. 54.

22 Цит. по: Ю. Борцов, Владимир Путин, Москва - Ростов н/Д. 2001, с. 378.

23 В. Соловьев, «Миропорядок 2018», https://www.youtube.com, доступ 07.03. 2018.

${ }_{24}$ Имидж тидера. Психологическое пособие для политиков, ред. Е.В. Егорова-Гантман, http:// www.forsuccess.ru, доступ 07.08.2018.
} 
например, перед губернаторскими выборами 1996 г., именно В. Путин проводил переговоры с огромным количеством депутатов, от которых зависело решение важного для Собчака вопроса о переносе даты голосования. Работая уже в Москве в должности заместителя главы Администрации Президента по региональным вопросам, В. Путин занимался налаживанием контактов с губернаторами и, по его признанию, «эта работа была самой интересной» ${ }^{25}$.

Принципиальное значение для руководителя страны имеет система выстраиваемых отношений с представителями политической элиты. По мнению политолога П. Ратленда, «Путину, пожалуй, не удалось создать единую элиту, действующую на основе консенсуса... Он скорее возвышается над раздробленной и разобщенной элитой, контролируя ее посредством кнута и пряника, патронажа и принуждения. Элита осознала свою нелегитимность в глазах общества, что позволило Путину контролировать ее» ${ }^{26}$. Подобное положение, с одной стороны, позволяет практически единолично принимать ключевые стратегические решения. С другой стороны, резко повышает ответственность в глазах простых граждан в архитектуре принимаемых политических решений современной России. В ноябре 2018 года Левада-центр провел исследование, согласно которому более половины опрошенных россиян (55\%) считают, что ответственность за проблемы в России и рост стоимости жизни несет президент Владимир Путин ${ }^{27}$.

По словам людей, работавших вместе с будущим Президентом, В. Путин никогда не рубит с плеча, поэтому для него лучшей характеристикой человека, стремящегося в президентскую команду, является умение выстоять в экстремальных условия ${ }^{28}$. Сам Владимир Владимирович считает, что в критических ситуациях остается чересчур спокойным. «Позже, когда я учился в разведшколе, мне в одной характеристике записали как отрицательную черту: „Пониженное чувство опасности". И этот недостаток считался очень серьезным» ${ }^{29},-$ вспоминал В. Путин. Тем не менее, создается впечатление, что именно в кризисных ситуациях, например, в ходе событий в Беслане 2004 года, урегулирования конфликта рабочих в Пикалево в июне 2009 года или присоединения Крыма в 2014 году, национальный лидер чувствует себя естественно, уверенно и прагматично.

По мнению политических аналитиков, 2014 год стал переломным для восприятия образа В. Путина в массовом сознании. В первую очередь, это связано с внешнеполитической ситуацией и последовавшим «Крымским консенсусом» в российском обществе. Политолог Е. Б. Шестопал по результатам исследования отмечает, что в этот период на первое место вышел образ «Путина-политика».

25 В. Путин, От первого лица: Разговоры с Владимиром Путиным, Москва 2000, с. 123.

26 П. Ратленд, Постсоветские элиты России, «Полис» 2016, №3, с. 58.

27 Россияне назвали ответственных за рост стоимости жизни, https://www.levada.ru, доступ 05.12.2018.

28 Цит. по: Ю. Борцов, Владимир Путин, Москва-Ростов н/Д. 2001, с. 368.

29 В. Путин, От первого тииа: Разговоры с Владимиром Путиным, Москва 2000, с. 123. 
При этом главной заслугой Путина опрошенные считают его внешнеполитические успехи и достойное отстаивание национальных интересов страны ${ }^{30}$.

По всей видимости, в команде советников Президента РФ находится ограниченный круг доверенных лиц, с которыми В. Путин может обсудить текущие политические вопросы, но его лидерский стиль, несомненно, проявляется в ходе этих совещаний. «И чаще всего происходят дискуссии и обмен мнениями, и в конечном итоге мне приходится принимать окончательные решения (курсив мой - Д.С.). И у нас выстроено таким образом, что после принятия решения все работают на то, чтобы это решение было реализовано» ${ }^{31}$, - подчеркивает глава государства.

Известный историк и публицист Рой Медведев точно заметил, что российский лидер очень осторожен и не любит принимать быстрых решений. Поэтому его трудно подставить. Но там, где это необходимо, он может принимать молниеносные решения, причем он способен на поступки, противоречащие ожиданиям большинства ${ }^{32}$. Вследствие чего, можно говорить о непредсказуемом характере в общей архитектуре политических решений национального лидера, многие из которых становятся достоянием общественности только после публикации принятого варианта решения.

На сегодняшний день Президент РФ является главным политическим ньюсмейкером в ходе формирования официальной общественно-политической повестки дня. Рассмотрим более подробно данный процесс в современной России.

\section{Основные тренды формирования повестки дня}

Вопрос о формировании повестки дня является фундаментальным для всей архитектуры системы принятия решений, т.к. в результате общественно-политического дискурса определяются основные векторы развития государства и только потом обсуждаемые варианты политических решений могут «цементироваться» в виде определенных нормативно-правовых актов.

Стоит отметить, что концепция политической повестки дня стала формироваться во второй половине 1960-х гг. в США в период проведения исследований американских специалистов по изучению роли СМИ в общественно-политических процессах. Авторы пытались выяснить механизм формирования политической повестки дня, степень осведомленности граждан о проблемах общества, изменение установок на основе полученной информации и реализации этих установок в поведении.

30 Е. Шестопал, Восприятие В.В. Путина российскими гражданами: 15 лет пребывания у власти, «Полис» 2015, №6, с. 79.

31 Путин рассказал о процессе принятия решений в сфере внешней политики, https://tass.ru, доступ 7.03.2018.

32 Р. Медведев, Владимир Путин - действующий президент, Москва 2002, с. 193. 
Однако необходимо понимать, что повестка дня является важным инструментом для формирования новых стандартов поведения, идеалов и «правил игры» в политической системе общества. В частности, как указывает политолог Е. Б. Шестопал, «повестка дня связывается с теми идеями, целями и ценностями, которые власть (и прежде всего исполнительная - отмечено Е.Б. Шестопал) кладёт в основу своей текущей политики. Иногда под повесткой дня понимаются «скрытые мотивы, лежащие в основе проводимой политики» ${ }^{33}$.

В данной работе, как отмечалось выше, мы постараемся показать основные тренды формирования современной политической повести дня России и рассмотреть некоторые интернет-технологии и инструменты, влияющие на ее развитие и трансформацию.

В начале стоит отметить, что в ходе установления повестки дня важное значение приобретает культура политического дискурса между представителями органов государственной власти и институтами гражданского общества. В нашей стране эта культура находится на низком уровне, т.к. зачастую власть самостоятельно определяет актуальные задачи без широкого привлечения научно-экспертного сообщества, партий, общественных структур и СМИ. Доминирование официальной точки зрения в публичном дискурсе не позволяет появлению взвешенных, альтернативных вариантов для включения в топ-список приоритетных политических вопросов. Выстроенная вертикаль власти, моноцентризм и атмосфера зависимости региональных политических субъектов от Центра задают условия только для транслирования идей федеральной власти без их осмысления, рефлексии и критического анализа. Именно поэтому в современных реалиях местные и региональные политические акторы обладают слабой повестокообразующей субъектностью, не позволяющей им самостоятельно определять приоритеты собственного общественного развития и эффективнее решать локальные проблемы.

Следующий тренд связан с проблемой смещения внутриполитической тематики в повестке дня России в сторону международной сферы. На протяжении последних лет официальные СМИ неизменно достаточно подробно освещают гражданскую войну в Сирии. Подчеркивается, что действия нашей страны соответствуют нормам международного права, т.к. поддерживается легальный режим президента Башара Асада, который официально обратился к России с просьбой о помощи. Решение по отправке российских ВВС было единодушно поддержано Советом Федерации Федерального Собрания РФ. Российские журналисты с риском для жизни снимали репортажи и документальные фильмы, освещая детали военной операции и будни простых военнослужащих на базе Хмеймим. Даже после объявления приказа президента В. В. Путина о начале вы-

33 Е. Шестопал, Политическая повестка дня российской власти и её восприятие гражданами, «Полис» 2011, № 2, с. 8. 
вода основной группировки из Сирии, обстановка в этом государстве продолжает оставаться в центре внимания российских СМИ.

Еще одна центральная тема информационно-аналитических программ и политических ток-шоу на телеканалах страны связана с ситуацией вокруг Донбас$\mathrm{ca}$, а также отношения с Украиной и США. При этом риторика приглашенных экспертов и гостей становится с каждым годом все более агрессивной и напористой. Данная особенность проявляется не только на уровне медийных персон-популистов, но и официальных представителей военных и дипломатических ведомств.

Следующая особенность, на наш взгляд, заключается в постепенном формировании альтернативной политической повестки дня в России. Сегодня можно говорить о существовании практически двух параллельных миров: официальные СМИ и интернет-сфера. Особую роль в этом процессе занимают социальные сети, в которых присутствует интерактивность и высокая оперативность распространения информации. Согласно данным Левада-центр, 74\% совершеннолетних россиян пользуются Интернетом. Пользователей непосредственно социальных сетей меньше, при этом наиболее популярными являются "ВКонтакте" и “Одноклассники", в которых общаются порядка двух третей всех пользователей социальных сетей (65\% и 63\% соответственно). Каждый третий пользуется социальными сетями и мессенджерами от получаса до часа в день, а каждый четвертый ежедневно проводит в них от одного часа до четырех ${ }^{34}$. В то же время сохраняется большой процент тех, кто регулярно смотрит телевизор и использует официальные СМИ для получения информации, но в молодежной среде растет число пользователей, которые узнают новости в основном из сети интернет. Именно в этой среде начинают функционировать новые способы коммуникации, культивироваться собственные ценности и идеалы, появляться образы политических героев, способных говорить на понятном языке и уже призывать к активным действиям. Таким образом, интеренет-сообщество выстраивает свою иерархию потребностей, целей и актуальных проблем, требующих первоочередного решения в реальной политической жизни. Поэтому на первый план выходят некоторые технологии и механизмы создания повести дня в нашей стране. Одним из таких действенных инструментов является краудсорсинг.

Данный термин появился в 2006 году, благодаря журналисту Джеффу Хау, который чуть позже написал книгу «Краудсорсинг: коллективный разум как инструмент развития бизнеса» (2009). Само понятие образовано от английских слов «толпа» и «аутсорсинг» - термина, обозначающего передачу за вознаграждение части бизнес-процессов на обслуживание профессионалам. Ключевым посылом данного подхода является утверждение, согласно которому в интернет-пространстве всегда найдутся люди, готовые бесплатно или за небольшое вознаграждение

34 «Пользование интернетом», https://www.levada.ru, доступ 18.01.2018. 
Pobrane z czasopisma Wschód Europy http://journals.umcs.pl/we

Data: 26/04/2023 14:07:41

Архитектура принятия политических решений в современной России...

делиться собственными идеями и создавать креативные продукты. В методах краудсорсинга активно применяются современные коммуникативные и информационные разработки, с использованием диалоговых интернет-площадок и социальных сетей. При этом существуют самые различные разновидности краудсорсинговых технологий. Например, в зависимости от типа поставленной задачи, выделяют: 1) голосование. Пожалуй, одна из самых распространенных и легкореализуемых техник, которая встречается в социальных сетях. На основе полученных данных составляются различные рейтинги, и выясняется общественное настроение граждан по тому или иному вопросу; 2) создание нового проекта или «наполнение контента». Самым известным примером является «Википедия», где контент создается аудиторией обычных пользователей интернета. С помощью данного подхода постепенно создается очень полная, актуальная и бесплатная база данных; 3) мониторинг ситуации и сбор информации.

В сфере политики для этих целей активно применяется законотворческий краудсорсинг, который стал использоваться для принятия важных государственных программ и законов. В частности, в конце июля 2011 года в Исландии была представлена новая конституция, в написании которой приняли участие простые граждане, а 23 октября 2012 года она была принята парламентом. В мировой правовой практике это событие можно назвать уникальным случаем подобного рода. В тоже время, форма законотворческого краудсорсинга встречается в Великобритании, Германии, Финляндии и т.д.

В России одним из пилотных проектов в сфере законодательства стала онлайн-платформа общественного обсуждения «Закона об Образовании». В ходе этой работы участники интернет-сообщества осуществляли экспертизу и оценивали поступающие предложения, комментировали и вносили собственные идеи. Представляется, что высшее руководство страны осознает важность подобных инициатив и старается их поддерживать. В частности, В. В. Путин в своей статье «Демократия и качество государства» писал: «Уже сейчас мы используем практику размещения проектов законов в интернете. Каждый может направить свое предложение или поправку. Они рассматриваются, а лучшие и содержательные - учитываются в финальной версии законопроекта» ${ }^{35}$.

Более того, В. В. Путин предложил обязательное правило рассмотрения в парламенте тех законодательных инициатив, которые соберут в интернете сто тысяч и более подписей, а сам тренд с публичным обсуждением законопроектов на основе технологии краудсорсинга был закреплен в феврале 2011 г. в Указе Президента «Об общественном обсуждении проектов федеральных законов».

В последнее время в нашей стране набирает популярность еще одна форма влияния на механизм формирования политической повестки дня - подписание интернет-петиций. По большому счету, это упрощенная модель волеизъявления человека, не предполагающая личное участие, например, в реальных акциях

35 В. Путин, Демократия и качество государства, http://www.kommersant.ru, доступ 06.02.2012. 
протеста, но оказывающее воздействие на трансформацию публичного информационного поля, из которого затем рождаются основные лейтмотивы повестки дня. В чем же преимущества подобного способа интернет-активности?

Во-первых, в случае большого числа подписавших петицию пользователей, официальные лица вынуждены реагировать на этот социальный заказ определенной группы населения. Однако необходимо пояснить, что для представителей государственной власти РФ такие петиции далеко не всегда являются основанием для комментариев. Скажем, несколько лет назад на сайте www.change.org было инициировано предложение об отставке премьер-министра Д. А. Медведева, которое подписало более 200000 участников этой онлайн-кампании. Петиция была адресована Президенту РФ, но осталась без внимания. Тем не менее, такие интернет-акции влияют на изменение политического имиджа политика и его рейтинг. Во-вторых, петиции являются сигналом общественного недовольства и поводом для политической дискуссии. Граждане обозначают свою позицию и тем самым способны оказывать публичное давление на бюрократический аппарат и лиц, принимающих управленческие решения. В-третьих, подписание петиции не требует значительных ресурсов и времени, а является оперативной практикой реагирования части активных и неравнодушных граждан. Возможно, именно подобные способы волеизъявления станут в будущем эффективными инструментами воздействия на политических лидеров.

Стоит отметить, что в России постепенно распространяются и другие механизмы привлечения общественного внимания и обращения к высшим лицам государства. В частности, проведение различных флешмобов и активно развивающаяся сфера блогов в интернете. Некоторые русскоговорящие блогеры на видеохостинге «Ютуб» имеют аудиторию в несколько миллионов пользователей. В своих роликах они высказываются и на политические темы, способствуя включению в текущую повестку дня конкретных вопросов и актуальных задач. Например, в 2017 году разгорелся скандал между банкиром Олегом Тиньковым и кемеровскими блогерами «Немагия», который вышел за пределы интернет-пространства. Интересно, что рассматриваемая ситуация стала предметом для обсуждения на заседании Государственной думы РФ и инициирование проектов по регулированию государством сети интернет. Политические аналитики, освещающие эту проблематику в СМИ, обратились напрямую к президенту В. В. Путину, который пообещал разобраться в этом конфликте.

\section{Выводы}

В современной политологии накопился солидный багаж методологических подходов и моделей для исследования политических решений. На наш взгляд, наиболее релевантной теоретической конструкцией анализа процесса принятия решений на федеральном и региональном уровнях РФ является модель колебательно-маятникового механизма принятия решений А. И. Соловьева, выполненная в рамках когнитивного подхода. В ней особое внимание уделяется политиче- 
Pobrane z czasopisma Wschód Europy http://journals.umcs.pl/we

Data: 26/04/2023 14:07:41

Архитектура принятия политических решений в современной России...

скому уровню в архитектуре принятия государственных решений, где ключевую роль играют политические лидеры.

В России ключевым политическим актором является Президент РФ В. В. Путин, в его политико-психологической характеристике стиля принятия решений можно обнаружить систематическое выражение личных качеств политического лидера, его отношение к методам решения задач, степень открытости к новой информации, склонность к риску, способность идти на компромисс и т.д. Оставаясь самым популярным политиком страны, Президент РФ способен существенно влиять на формирование политической повестки дня.

Проанализированные практики и интернет-технологии не являются панацеей от всех общественно-политических проблем, но могут рассматриваться как работающие инструменты для включения в политическую повестку дня актуальных проблем, благодаря чему возможно задействовать потенциал информационно-коммуникативных ресурсов, способствовать повышению открытости органов государственной власти, созданию условий для реализации общественно значимых инициатив и принятия продуманных политических решений.

Аннотация: В статье рассматриваются основные черты архитектуры принятия политических решений в современной России в контексте президентской вертикали власти В. В. Путина с точки зрения возможных методологических подходов для их анализа и исследования. Рассматривается политико-психологическая характеристика стиля принятия решений Президента РФ как доминирующего субъекта в процессе формирования политической повестки дня и ее основные тренды развития. Анализируются нетрадиционные инструменты влияния на механизм трансформации повестки дня в интернете. В частности, технологии краудсорсинга, практика созданий петиций и блогосфера.

Ключевые слова: принятие политических решений, стиль принятия решений, политическая повестка дня, тренды формирования, краудсорсинг, петиции, блогосфера, современная Россия.

\section{Architektura podejmowania decyzji politycznych we współczesnej Rosji w kontekście prezydenckiego pionu władzy Władimira Putina}

Streszczenie: Artykuł omawia główne cechy architektury podejmowania decyzji politycznych we współczesnej Rosji w kontekście prezydenckiego pionu władzy W. Putina z punktu widzenia możliwych podejść metodologicznych do ich analizy i badań. Uwzględniono polityczną i psychologiczną charakterystykę stylu decyzyjnego Prezydenta Federacji Rosyjskiej jako podmiotu dominującego w procesie kształtowania programu politycznego i jego głównych trendów rozwojowych. Analizowane są nietradycyjne narzędzia oddziaływania na mechanizm transformacji agendy w Internecie. W szczególności technologie crowdsourcingu, praktyka tworzenia petycji i blogosfery.

Słowa kluczowe: podejmowanie decyzji politycznych, styl decyzyjny, agenda polityczna, trendy formacyjne, crowdsourcing, petycje, blogosfera, współczesna Rosja. 


\section{Architecture of policy decision-making in modern Russia in the context of the presidential vertical power Vladimir Putin}

Annotation: The article considers the main features of the architecture of political decisionmaking in modern Russia in the context of the presidential vertical of power V.V. Putin in terms of possible methodological approaches for their analysis and research. The political and psychological characteristic of the decision-making style of the President of the Russian Federation as the dominant subject in the process of forming the political agenda and its main development trends are considered. Non-traditional tools of influence on the mechanism of transformation of the agenda on the Internet are analyzed. In particular, crowdsourcing technologies, the practice of creating petitions and the blogosphere.

Keywords: political decision making, decision making style, political agenda, formation trends, crowdsourcing, petitions, blogosphere, modern Russia.

\section{Источники и литература}

\section{Монографии и научные статьи}

B'yukenen Dzh., Konstitutsiya ekonomicheskoy politiki, „Voprosy ekonomiki” 1994, №6.

Bateneva T., Neopoznannyy shagayushchiy ob"yekt, „Izvestiya", 16.02.2000.

Bortsov Yu., Vladimir Putin, Moskva-Rostov n/D, 2001.

Dal' R., Demokratiya i eye kritiki (per. s angl.), Moskva 2003.

Galkin A., Korporativizm kak forma otnosheniy mezhdu gosudarstvom i obshchestvom: predely i opasnosti, „Politicheskiye issledovaniya” 2000, №6.

Gavrilova M., Kognitivnyye i ritoricheskiye osnovy prezidentskoy rechi (na materiale vystupleniy V.V. Putina i B.N. El'tsina), Sankt-Peterburg 2004.

Kulagin 0., Prinyatiye resheniy v organizatsiyakh, Sankt-Peterburg 2001.

Medvedev R., Vladimir Putin - deystvuyushchiy prezident, Moskva 2002.

Menli Dzh., Neoplyuralizm: analiz dvukh vidov plyuralizma s pozitsiy klassovoy teorii, [v:] Teoriya i praktika demokratii. Izbrannyye teksty (per. s angl.), red. V. L. Inozemtsev, B. G. Kapustin, Moskva 2006. Pechenev V., Vladimir Putin - posledniy shans Rossii?, Moskva 2001.

Pocheptsov G., Strategicheskiy analiz: strategicheskiy analiz dlya politiki, biznesa i voyennogo dela, Kiyev 2004.

Putin V., Ot pervogo litsa: Razgovory s Vladimirom Putinym, Moskva 2000.

Ratlend P., Postsovetskiye elity Rossii, „Polis” 2016, №3.

Raygorodskiy D., Psikhologiya i psikhoanaliz vlasti, T. 2. Khrestomatiya, Samara 1999.

Shestopal E., Politicheskaya povestka dnya rossiyskoy vlasti i eyë vospriyatiye grazhdanami, „Polis" 2011, № 2 .

Shestopal E., Vospriyatiye V.V. Putina rossiyskimi grazhdanami: 15 let prebyvaniya u vlasti, „Polis” 2015, №6.

Shmitter F., Uvyazka interesov i upravlyayemost' politicheskikh rezhimov v sovremennoy Zapadnoy

Evrope i Severnoy Ameriki, [v:] Teoriya i praktika demokratii. Izbrannyye teksty (per. s angl.), red. V.L. Inozemtsev, B.G. Kapustin, Moskva 2006. 
Pobrane z czasopisma Wschód Europy http://journals.umcs.pl/we

Data: 26/04/2023 14:07:41

Архитектура принятия политических решений в современной России...

Solov'yev A., Kolebatel'no-mayatnikovyy mekhanizm prinyatiya gosudarstvennykh resheniy: k obosnovaniyu kognitivnoy modeli (II), „Politicheskiye issledovaniya” 2005, №6.

\section{Интернет источники}

Batenko T., Portret Putina: vopros nad otvetami, http://www.day.kiev.ua

Imidzh lidera. Psikhologicheskoye posobiye dlya politikov, red. E.V. Egorova-Gantman, http://www.forsuccess.ru

«Pol'zovaniye internetom», https://www.levada.ru

Poslaniye Prezidenta Rossii V. Putina: Poslaniye Prezidenta RF Federal'nomu Sobraniyu, http://www. kremlin.ru

Putin V., Demokratiya i kachestvo gosudarstva, http://www.kommersant.ru

Putin V., Otvety na voprosy na Vsemirnom kongresse informatsionnykh agentstv «Informatsiya: vyzovy XXI veka», http://www.kremlin.ru

Putin rasskazal o protsesse prinyatiya resheniy v sfere vneshney politiki, https://tass.ru

Rossiyane nazvali otvetstvennykh za rost stoimosti zhizni, https://www.levada.ru

Solov'yev V., «Miroporyadok 2018», https://www.youtube.com 